\title{
Co-operative research
}

\section{Promotion of co-operative research: a Spanish experience}

\author{
Juan Acosta Ballesteros and Aurelia Modrego Rico
}

The aim of this paper is to assess the success of the Spanish technology policy instrument 'proyectos concertados' (co-operative projects which receive public financing) in the stimulation of co-operation between firms and public research centres (PRCs). The paper analyses the factors which explain the different impact of this aid in relation to: a) whether or not the public intervention has contributed to getting a project carried out co-operatively which would otherwise have been carried out by the firm alone; b) whether or not the firms which have carried out proyectos concertados intend to continue to co-operate with the participant PRCs. The information used corresponds to the opinion of the firm which undertakes the proyecto concertado.
Juan Acosta Ballesteros is at Universidad de La Laguna, Facultad de Ciencias Económicas y Empresariales, Campus de Guajara, 38201 La Laguna (Santa Cruz de Tenerife), Spain; Tel: +34 922 317116; Fax:+34 922 253742; E-mail: Jacosta@ull.es. Aurelia Modrego Rico is at Universidad Carlos III de Madrid, Calle Madrid 126, 28903 Getafe (Madrid), Spain; Tel: +34 91 6249888; Fax: +34 91 6249517; E-mail: Modrego@eco.uc3m.es.

The authors are grateful to Olga Rodríguez and an anonymous referee for useful comments and suggestions. Information contained in this paper has been obtained thanks to the collaboration of the Centre for Industrial Technological Development (CDTI). This study has received financing from the National R\&D Plan (Project SEC97-1331).

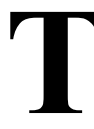
THE LACK OF INTERRELATION in Spain between the research conducted by firms and that which is carried out by public research centres (PRCs) has led to the integration in science and technology policies of instruments which facilitate the articulation of the science-technologyindustry system. This paper centres on the technology policy instrument proyectos concertados, which awards interest-free loans to precompetitive research projects carried out by firms with the participation of at least one PRC research team. The aim is to analyse the success of these projects in stimulating cooperation between firms and PRCs.

Evidence is obtained as to the reasons which explain both that the proyecto concertado makes the firm co-operate with a PRC when it would otherwise have carried out the research alone, and that, after completing the proyecto concertado, the firm continues to collaborate with the participant PRC. To sum up, a study is made of the influence of public intervention on the generation of co-operation and its impact on the continuation of this co-operation. To be more specific, this paper revolves around the following two questions:

In the absence of public funding, would the firm have carried out the research project with the participation of the PRC? A negative response to this question would indicate that the proyecto concertado has generated co-operation.

Do those firms which have received funding intend to continue to collaborate with the PRCs which participated in the proyectos concertados? Affirmative responses indicate that collaboration will continue without public aid. 
Juan Acosta is a doctor in Economic and Business Sciences from Universidad de La Laguna (1996) and a University Specialist in Science and Technology Analysis and Management from Universidad Carlos III de Madrid (1993). He is an Associate Professor at Universidad de La Laguna. His main line of research is the study of government policy in support of co-operative research between firms and public research centres. In addition, he is currently working with the Canary Island Government (General Management Division for Universities and Research) to draw up the Plan for Research Excellence in the Canaries.

Aurelia Modrego is an Associate Professor in the Department of Economics, University Carlos III de Madrid, BA in Mathematics and Economics, and PhD in Economics (University of Vasque Country). Her fields of specialization are evaluation of R\&D policies, economics of innovation, human capital, and applied econometrics. She has been Deputy Director of Research in the Ministry of Education and Science and responsible for evaluation of projects in the National Agency of Evaluation and Prospective.

To achieve the objective, use is made of the information obtained by Modrego (1995) through a questionnaire that was sent to firms which had undertaken a proyecto concertado from the time they were first introduced until 1993. This survey was commissioned by the Centre of Industrial Technological Development (CDTI), which is the public agency that manages the proyectos concertados. Bearing in mind that the answers are categorical, the method used in this article consists of estimating ordered probit models which explain the answers from firms to the two questions.

The main conclusion is that proyectos concertados have encouraged co-operation between firms and PRCs, and that this co-operation has been continued after the end of the research projects in the cases for which information from the survey is available. This suggests that proyectos concertados as a science policy tool has been effective.

This paper identifies the factors which influence the generation of co-operation and continuation, and its importance is quantified. In addition to other factors, the paper analyses: the impact of the size of the firm; its co-operative research experience; the reasons which have led firms to co-operate; their difficulties in financing research projects; and any problems which may have arisen during the joint research project.

The paper is organised as follows: the main public actions in Spain to foster collaboration between firms and PRCs are summarised, including the proyectos concertados. Then the survey is described and the data used to estimate the models are presented. The results obtained from the estimations are analysed and finally some conclusions are offered.

\section{Public policies for co-operative research}

The National R\&D Plan sets the priorities for action, programmes the resources available and integrates activities in $\mathrm{R} \& \mathrm{D}$ in the productive sectors, research organisms and universities. It was adopted in 1988: since then, the Spanish Government has used a set of instruments to promote communication and concerted action between universities and public research organisms and firms. These actions are basically:

The network of research results transfer offices (OTRI network) is made up of small units (OTRIs) situated in universities, public research organisations, and business research associations. Their function is to promote the transfer of the scientific-technical output of universities and public research organisations to the productive sectors. OTRIs deal with the contracts between researchers and firms, and with their administration. In 1997, they dealt with 34,565 contracts worth a total of 226.6 million euros (1.14 US dollars/euro): $47 \%$ was for R\&D activities, $22 \%$ for technical support and the rest was shared between agreements on collaboration, training and services. To carry out their task, the OTRIs have built up a database of scientific-technological output (DATRI), covering 7,545 research teams.

The OTRI network uses the Programme to Stimulate the Transfer of Research Results (PETRI) to encourage basic and applied research groups to devote a part of their efforts to R\&D activities, the results of which can be transferred to firms. The PETRI serves to support the first stage of transfer of technology from PRCs to firms.

Proyectos concertados and co-operative projects ${ }^{1}$ are also oriented towards improving the articulation of the science and technology system. Proyectos concertados attempt to foster collaboration by firms and PRCs in precompetitive research projects. Co-operative projects fund collaboration between firms and technological centres.

The link between firms and PRCs extends to the exchange of personnel. Worth mentioning are the grants for writing a doctoral thesis in firms and mechanisms to incorporate doctors into firms.

In addition to the National R\&D Plan, the Centre of Industrial Technological Development (CDTI) has been created. This is a public agency which administers most of the public funds devoted to facilitating business innovation in Spain. In fact, its proximity to

Table 1. PETRI, proyectos concertados and co-operative projects

\begin{tabular}{lccc}
\hline & $\begin{array}{c}\text { Number of } \\
\text { projects } \\
\text { approved }\end{array}$ & $\begin{array}{c}\text { Public } \\
\text { funding } \\
\text { ('000s euros) }\end{array}$ & $\begin{array}{c}\text { Total budget } \\
\text { ('000s euros) }\end{array}$ \\
PETRI & 88 & 3967.7 & 7611.2 \\
$\begin{array}{l}\text { Proyectos } \\
\text { concertados }\end{array}$ & 53 & 16773.6 & 38008.6 \\
$\begin{array}{l}\text { Co-operative } \\
\text { projects }\end{array}$ & 17 & 4440.9 & 9797.7 \\
\hline $\begin{array}{l}\text { Source: } \\
\text { Comision Interministerial de Ciencia y Tecnologica }\end{array}$ & & &
\end{tabular}


Table 2. Would co-operation have taken place without public aid?

\begin{tabular}{llc}
\hline Variable & Response & Frequency \\
& & \\
$\mathrm{COS}=0$ & Improbable & 50 \\
$\mathrm{COS}=1$ & Not very probable & 133 \\
$\mathrm{COS}=2$ & Probable/very probable & 98 \\
\hline
\end{tabular}

the business world has led it to manage the concerted and co-operative projects. The CDTI also plays an active role in the promotion of co-operative research, especially between firms.

Proyectos concertados are an important instrument among the various public activities to promote cooperative research. Table 1 provides information on the resources used in 1997 by the PETRI, proyectos concertados and co-operative projects. It shows that the proyectos concertados represent $68.6 \%$ of the total projects' budgets and $66.6 \%$ of the public funding.

\section{Research design}

\section{Sample characteristics and data collection}

This paper uses the data provided by a survey carried out by Modrego (1995), which was commissioned by the CDTI to assess the proyectos concertados. ${ }^{2}$ For this survey, the CDTI's administrative database was used. The information supplied is about Spanish firms that participate in the proyectos concertados with at least one PRC. After analysis of the data about the companies involved, a questionnaire was designed to gather additional qualitative and perceptual information.

In the development of the survey, a pilot questionnaire was initially sent to ten companies to help validate the questions. The final version of the questionnaire along with a letter of presentation of CDTI, which encouraged the responses, was sent by mail. The questionnaire was personalised and even some of its data were filled in according to CDTI's database, asking companies to review them for accuracy. The form was distributed among 317 firms which had applied for a total of 496 proyectos concertados during the period 1988 to 1993.

After a reasonable length of time for the receipt of answers, a follow up letter, together with a new copy of the questionnaire was sent to approximately $70 \%$ of

Table 3. Does the firm intend to continue co-operating with the participant PRC(s) in the future?

\begin{tabular}{llc}
\hline Variable & Response & Frequency \\
& & \\
$\mathrm{COP}=0$ & Improbable/not very probable & 37 \\
$\mathrm{COP}=1$ & Probable & 115 \\
$\mathrm{COP}=2$ & Very probable & 129 \\
\hline
\end{tabular}

\section{To explain whether public aid has generated co-operation with public research centres or, on the contrary, the co-operation would have taken place anyway, it is necessary to determine the motives behind the firm carrying out the project jointly}

the sample of projects. This second mailing was reinforced with telephone calls that also helped to solve the problem of 'no answer' to some of the questions. In the end, 118 companies responded to the questionnaire, which resulted in information on a total of 281 projects, $56.65 \%$ of the project sample.

\section{Co-operation and continuation}

The survey by Modrego (1995) is wide-ranging, and the information which seems relevant to explain the generation of co-operation and continuation has been singled out. The variables used in the estimation of the models are presented here.

Tables 2 and 3 show the frequency of response of firms to the two questions which constitute the subject of this article. The answers are on a scale of values from 'improbable' to 'highly probable', through 'not very probable ' and 'probable'. The proyectos concertados have proved to encourage co-operation in 183 cases, this effect being especially important in the 50 projects in which co-operation would otherwise have been improbable. Since the answer 'very probable' was only given in 26 cases, it was decided to merge it with the 'probable' category. ${ }^{3}$ The prolongation of co-operation is also considered since, except in 37 projects in which a continuing link with the PRC would be improbable or not very probable (10 gave the answer 'improbable'), the firms express their intention to continue co-operating.

The estimation of the effect that the characteristics of the firms and the projects have on the firms' two answers is made through an ordered probit model for each of the dependent variables (COS and COP).

To explain whether public aid has generated co-operation with PRCs or, on the contrary, the cooperation would have taken place anyway, it is necessary to determine the motives which move the firm to carry out the project jointly. In the absence of public intervention, the firm will only choose to carry out the project in co-operation if the advantages of doing so are greater than the disadvantages.

Advantages are cost reduction, access to installations or qualifications not available within the firm, and so on. ${ }^{4}$ Disadvantages include cultural barriers, disparity between firms and PRCs in the orientation of the research, the perception within the firm that the university researchers do not understand the 
necessities of industry or that they do not have the appropriate skills, patent policies, difficulties in the protection of publication rights, and so on. ${ }^{5}$

When firms have access to proyectos concertados, two possibilities exist:

If the firm was willing to co-operate even without the proyecto concertado, it will be interested in public funding if its advantages in terms of financial saving compensate for the disadvantages which contact with the public agency may mean (in terms of the application of the project and its monitoring).

If the firm had decided not to co-operate, the advantages of the proyecto concertado would have to be sufficient to compensate also for the disadvantages of collaboration with a PRC. When looking at the behaviour of firms, it must be remembered that it is not always possible to carry out a project without public resources. So, the provision of funds from the proyecto concertado (involving cooperation with PRCs) may lead firms which would otherwise have preferred to conduct research alone to carry it out in co-operation, otherwise they may have been unable to carry it out at all because of financial constraints. In these cases, the benefits of the proyecto concertado do not compensate for the disadvantages of co-operation, but the evaluation of the project is positive, that is to say, the firm would rather undertake it even in collaboration. ${ }^{6}$

To explain the firms' response as to whether or not they would have collaborated with PRCs in the absence of a proyecto concertado, it is therefore necessary to introduce variables which cover the importance of the PRC contribution to the project in question, the previous experience of the firm in cooperating with PRCs and the problems faced in financing research projects. The reasons why cooperation is not especially desirable for the firm, as well as the financial problems, mean that the firm tends to respond that it would not have collaborated if it were not for the proyecto concertado. Since the sample of projects available only includes those which have been carried out in co-operation and with the aid of a proyecto concertado, in every case the benefits of the proyecto concertado (presumably associated with favourable financial terms) compensate for the possible disadvantages of co-operation.

\section{Generation of co-operation}

Starting with the first equation about the generation of co-operation, the undertaking of the project with PRC intervention without the aid of a proyecto concertado depends, in the first place, on the characteristics of the firm (Table 4). These characteristics have been included through dummy variables which indicate the firms' size, measured by number of staff, and two variables, also dichotomic, which indicate whether or not the firm had previously carried out a proyecto

\section{Table 4. Characteristics of the firm}

$\begin{array}{lll}\text { Staff } & & \\ & & \\ \text { P1 }=1 & \text { Up to } 25 \text { employees } & 47 \\ \text { P2 }=1 & \text { Between } 26 \text { and } 100 \text { employees } & 55 \\ \text { P3 }=1 & \text { Between } 101 \text { and } 250 \text { employees } & 51 \\ \text { P4=1 } & \text { Between } 251 \text { and } 1000 \text { employees } & 68 \\ \text { P5 }=1 & \text { More than } 1000 \text { employees } & 60\end{array}$

Had they previously participated in another proyecto concertado?

PCS $=1 \quad$ Yes

Was there any previous experience of joint work with a PRC? (which was not a proyecto concertado)

COLNPC $=1$ Yes

Note: a This table and those that follow indicate the dichotomic variables with the description corresponding to value one and the number of questionnaires in which the dummy variable adopts this value

concertado and whether it had previously maintained any links with PRCs (contracted research, participation in PETRI activities, joint participation in national R\&D programmes, joint participation in European R\&D programmes, and so on).

From the information contained in Table 4 , it can be deduced that, in $35 \%$ of the projects, the firms had previously carried out proyectos concertados and $39 \%$ of firms indicated the existence of another type of link. For the other $26 \%$, the proyecto concertado was their first experience of collaboration with PRCs.

Secondly, the intervention of PRC researchers is made dependent on the characteristics of the research conducted (Table 5), particularly on the degree to which the public-sector research work is necessary (or more important). Furthermore, in this case, the expectations the firm had with regard to the joint work with the PRC are important.

The first variable is the importance the firm gives to the PRC's participation as regards the viability of the project which, although it refers to an ex post facto opinion, may have been anticipated at the project's outset. This is a dummy variable which takes on the value 1 when it is considered probable or very probable that the project would have been viable in the absence of PRC participation. The responses suggest that $48 \%$ of projects would not have been feasible without co-operation.

The motives which have led firms to co-operate and the specific contributions made by the PRCs have also been taken into account. In both cases it is usual to mention more than one, as shown by the frequency of answers in Table 5.

In more than half the questionnaires co-operation with the PRC is justified by the acquisition of experience or knowledge (MC1), monitoring of technological or scientific advances in specific fields (MC2), access to specialities or qualifications not available within the firm (MC3) and access to research 
Do you consider that the project would have been viable without the co-operation of the PRC?

$\mathrm{FACA}=1$

Indicate which reasons led you to co-operate with the PRC.

MC1: Acquisition of experience or knowledge

MC2: Monitoring of technological or scientific advances in specific fields

MC3: Access to specialities or qualifications not available within the firm

mentioned

MC4: Access to research infrastructures not available within the firm

mentioned

MC5: Lower cost of carrying out the project for the firm

mentioned

MC6: Fulfilment of the necessary conditions to obtain funding

mentioned

Technically the contribution of the PRC can be described as:

APC1: New methods or techniques

mentioned

APC2: Test and measurement

mentioned

APC3: Designs

mentioned

APC4: Technical advice

mentioned

APC5: New tools and instruments

mentioned

APC6: Simulations

mentioned

APC7: Prototypes/pilot plant

mentioned

infrastructures not available within the firm (MC4). Around 35\% of the responses indicate lower cost of carrying out the project for the firm (MC5) and fulfilment of the necessary conditions to obtain funding (MC6). The most cited technical contributions of the PRC are new methods or techniques (APC1), test and measures (APC2) and technical advice (APC4).

The third group of variables refers to the financing needs of the firm, which in some cases may lead it to accept a co-operative venture which it would not otherwise have wanted or which, in other cases, explains the establishment of a collaboration which it was not possible to finance. As well as the three dichotomic variables which appear in Table 6, the variable MC6 from Table 5 provides similar information.

While the variables from Table 6 show the additional nature of the public funds (whether the funding leads firms to carry out projects which they would not have been able to finance $(62 \%)$ or to carry them out sooner $(51 \%)$ or with more resources $(60 \%))$, variable MC6 may refer to those firms which would have carried out the project on their own (they could have financed it), but preferred to co-operate in order to

Table 6. Variables which cover the additional nature of the proyectos concertados

\begin{tabular}{|c|c|c|c|}
\hline \multicolumn{4}{|c|}{$\begin{array}{l}\text { Evaluate the importance public funding has had in the } \\
\text { following: }\end{array}$} \\
\hline EF1: & $\begin{array}{l}\text { Making you decide to carry out } \\
\text { a project which would not } \\
\text { otherwise have been undertaken }\end{array}$ & $\begin{array}{l}\text { great/very } \\
\text { great }\end{array}$ & 175 \\
\hline EF2: & $\begin{array}{l}\text { Spending more resources on the } \\
\text { project than the firm alone would } \\
\text { have been able to spend }\end{array}$ & $\begin{array}{l}\text { great/very } \\
\text { great }\end{array}$ & 168 \\
\hline EF3: & $\begin{array}{l}\text { Starting the project before it would } \\
\text { otherwise have been started by } \\
\text { the firm alone }\end{array}$ & $\begin{array}{l}\text { great/very } \\
\text { great }\end{array}$ & 144 \\
\hline
\end{tabular}

receive the favourable terms of financing (35\%). These firms, then, are more interested in the reduction in costs than in the funds themselves (or at least they are able to finance the project by other means).

Between 1988 and 1999, the National Plan prioritised R\&D activities in specific technological areas known as national programmes. ${ }^{7}$ A group of dummy variables have been included which cover the different national programmes (Table 7) in which the proyectos concertados may be included.

Lastly, taking into account that some firms carry out more than one proyecto concertado and that, consequently, they have answered more than one questionnaire, the dummy variable $\mathrm{NC}$ has been added, which takes a value 1 in 155 cases.

\section{Generation of continuation}

This paper also explores whether, after a proyecto concertado, the firms wish to continue co-operating with the participant PRC. The reasons which explain continued co-operation are similar to those put forward in answer to the first question. On the one hand, firms will tend to continue co-operating if their

Table 7. National programmes

\begin{tabular}{lll}
\hline AR & Advanced Automatisation and Robotics & 27 \\
BIO & Biotechnology & 13 \\
ESP & Space Research & 28 \\
FORM & Environment and Natural Resources & 20 \\
ALI & Agriculture and Stockbreeding Research & 56 \\
MAT & New Materials & 85 \\
FAR & Health and Pharmacy & 26 \\
TIC & Information and Communication Technologies & 26 \\
\hline Note: ${ }^{a}$ & This is the dummy variable excluded from the estimated \\
& equations &
\end{tabular}




\section{The firms' evaluation of co-operation is predominantly positive: the frequency with which difficulties are said to have arisen is low, especially if it is taken into account that the firm may mention more than one difficulty}

evaluation of the work carried out in conjunction with PRCs is positive in general and, even more importantly, if the specific contribution of the participant $\mathrm{PRC}$ is of interest.

On the other hand, if the motive behind cooperation was to receive the financing for a proyecto concertado, we would expect co-operation to end as soon as funding is withdrawn. Of course, the situation is now somewhat altered because of the firm's experience during the proyecto concertado. As a consequence, the relevant factors when it comes to explaining the firm's initial decision must now include those factors which provide information about the firm's degree of satisfaction with the work in conjunction with the PRC, which may lead it to maintain a sustained relationship. ${ }^{8}$

In the equation explaining the persistence of co-operation, the same variables have been introduced which are used to explain co-operation in the absence of proyectos concertados: ${ }^{9}$ information has been added about the difficulties which the project has had to face because of the relationship between the firm and the PRC, and about the project's success. It must be noted that the firms' evaluation of co-operation is predominantly positive. The frequency with which difficulties are said to have arisen is low, as can be seen in Table 8, especially if it is taken into account that the firm may mention more than one difficulty.
Most frequently cited difficulties (22\% approximately) are lack of interest from the PRC team in the project or breach of deadlines by the PRC (DC5), and formal and bureaucratic requirements in the cooperation agreements (DC7). Higher costs than would have been incurred had the firm carried out the project alone (DC2), lack of resources in the firm (DC3), co-ordination problems between firm and PRC (DC4), and cultural barriers between firm and PRC (DC6) are difficulties cited in $10 \%$ of the questionnaires. In only $5 \%$ of projects were there problems caused by the lack of technical/scientific competence within the PRC team (DC1), or lack of confidentiality of the results (DC8), or problems relating to intellectual/industrial property rights (DC9).

The dichotomic variable EXPA is also included, indicating the degree to which the firm's expectations have been met. It is worth noting that in 224 cases $(79.7 \%)$ the degree of satisfaction was 'very high'.

\section{Results}

The following two subsections show the results from the estimation of the models to analyse the answers to the two questions central to this paper. Since variables COS and COP are split in to categories, two ordered probit models have been estimated.

Before explaining the results, it is necessary to point out that the firms' answers to the questions relative to the generation of co-operation and its continuation may be related or, to put it another way, there may be unobserved factors which simultaneously affect the firms' decision to co-operate without a proyecto concertado and to continue collaborating with the same PRC after the project. For this reason, a bivariate probit model was estimated. To do this the response categories to each question have been grouped together into just two.

The results obtained are very similar, at least

Table 8. Difficulties and final appraisal of co-operation

Co-ordination problems with the PRC have got in the way of the technical objectives of the project

DL3=1

Yes

Difficulties which affected co-operation between firm and PRCs

DC1: Lack of technical/scientific competence on the part of the PRC team

Mentioned $\quad 14$

DC2: Higher costs than would have been incurred had the firm carried out the project alone

Mentioned $\quad 35$

DC3: Lack of resources in the firm

Mentioned $\quad 36$

DC4: Co-ordination problems between firm and PRC

DC5: Lack of interest from the PRC team in the project or breach of deadlines by the PRC

DC6: Cultural barriers between firm and PRC

DC7: Formal and bureaucratic requirements in the co-operation agreements

Mentioned $\quad 63$

DC8: Problems relating to lack of confidentiality of results

Mentioned $\quad 18$

DC9: Problems relating to intellectual/industrial property rights

Mentioned

Evaluate to what degree the results of the project have coincided (or are expected to coincide) with initial expectations 
Table 9. Ordered probit model: the generation of co-operation

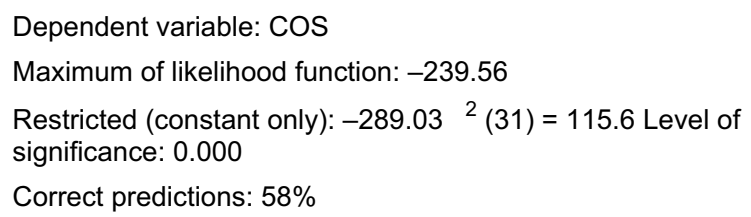

\begin{tabular}{|c|c|c|c|}
\hline Variable & Coefficient & t-student & Significance \\
\hline Constant & 0.762 & 1.62 & 0.104 \\
\hline $\mathrm{P} 1$ & 0.210 & 0.68 & 0.491 \\
\hline P2 & 0.244 & 0.79 & 0.427 \\
\hline P3 & 0.327 & 1.15 & 0.250 \\
\hline P4 & 0.142 & 0.54 & 0.586 \\
\hline COLNPC & -0.184 & -0.91 & 0.362 \\
\hline PCS & -0.114 & -0.48 & 0.624 \\
\hline FACA & 0.104 & 0.61 & 0.536 \\
\hline MC1 & 0.284 & 1.53 & 0.124 \\
\hline MC2 & -0.228 & -1.18 & 0.237 \\
\hline MC3 & 0.441 & 2.77 & 0.005 \\
\hline MC4 & 0.326 & 1.83 & 0.066 \\
\hline MC5 & -0.002 & -0.01 & 0.987 \\
\hline MC6 & -0.260 & -1.34 & 0.179 \\
\hline EF1 & -0.683 & -3.72 & 0.000 \\
\hline EF2 & 0.110 & 0.63 & 0.526 \\
\hline EF3 & -0.214 & -1.28 & 0.200 \\
\hline AR & -0.232 & -0.57 & 0.564 \\
\hline $\mathrm{BIO}$ & -0.281 & -0.58 & 0.556 \\
\hline ESP & -0.084 & -0.21 & 0.833 \\
\hline FORM & -0.065 & -0.16 & 0.870 \\
\hline ALI & -0.304 & -0.83 & 0.406 \\
\hline MAT & -0.206 & -0.61 & 0.535 \\
\hline FAR & 0.481 & 1.16 & 0.246 \\
\hline APC1 & 0.190 & 1.03 & 0.299 \\
\hline APC2 & 0.089 & 0.47 & 0.636 \\
\hline APC3 & 0.124 & 0.59 & 0.550 \\
\hline APC4 & 0.187 & 0.11 & 0.908 \\
\hline APC5 & -0.208 & -0.82 & 0.409 \\
\hline APC6 & -0.046 & -0.2 & 0.841 \\
\hline APC7 & 0.576 & 2.49 & 0.012 \\
\hline NC & 0.537 & 2.68 & 0.007 \\
\hline (1) & 1.640 & 12.46 & \\
\hline
\end{tabular}

qualitatively, to those of the ordered probits. Furthermore, the parameter which measures the correlation between the perturbations of both equations, is not significant. We could deduce from this that the unobserved effects on the generation of R\&D do not influence continuation (and vice-versa). As a consequence, the estimations of the two ordered probits considered individually appear to be adequate.

\section{Generation of co-operation}

The results of the ordered probit which explains to what degree the firm would have co-operated with a
PRC in the absence of a proyecto concertado are shown in Table 9. There are no differences to be seen in the responses according to the size of the firm, except that those with a staff of between 101 and 500 employees (P3) tend to co-operate more without a project than the rest. Neither the existence of previous experience in co-operation, whether in the context of a proyecto concertado (PCS) or any other type of relationship (COLNPC), nor the contribution of the PRC to the project's viability (FACA) influences the decision to carry out the project in conjunction with a PRC.

The most important reasons for co-operation are access to qualifications which are not available within the firm (MC3), access to infrastructures (MC4) and, to a lesser extent, the acquisition of experience or knowledge (MC1). Monitoring technological or scientific advances in specific areas (MC2) does not appear to be a motive for co-operation in the absence of public intervention. With regard to the PRCs' contribution, only when there are prototypes or pilot plants (APC7) does co-operation tend to take place without the proyecto concertado.

Considering the effect of public financing, it can be seen that those firms which have carried out the project thanks to public intervention (EF1) or, at least, have started it earlier than they would have otherwise (EF3), would not have co-operated without the project. These results are perhaps due, not to firms' lack of interest in co-operation, but to this co-operation not being established because the project would not have been undertaken. This might be the reason why those firms which indicate that the proyecto concertado meant the research enjoyed more resources do not tend to co-operate more when awarded a proyecto concertado (EF2). The firms which claim that the reason for co-operation is the fulfilment of the programme's conditions to receive funding (MC6) logically show less interest in co-operation without public intervention.

None of the dummy variables which cover the differential effect of the national programmes in relation to information and communication technologies (TIC) are significant. On the other hand, firms which have answered more than one questionnaire would have co-operated with a PRC more frequently than those which have only answered one.

Finally, the parameter (1) of the ordered probit is positive and very significant, indicating that when the latent variable which measures the firms' interest in co-operation in the absence of a proyecto concertado is over the value 1.64, firms state that the project would probably or very probably have been carried out without the proyecto concertado.

The ordered models raise difficulties when it comes to interpreting the effect of changes in the dependent variables on each of the probabilities of response, since in the immediate response categories in this case the answer 'not very probable' - a certain amount of ambiguity arises in relation to their sign (see, for example, Greene, 1991, pages 672-676). To 
Table 10. Variation in the probability of response in the face of changes in the independent variables ${ }^{a}$

\begin{tabular}{lccc}
\hline Variable & Improbable & $\begin{array}{c}\text { Not very } \\
\text { probable }\end{array}$ & $\begin{array}{c}\text { Probable or } \\
\text { very probable }\end{array}$ \\
P3 & -0.058 & -0.064 & 0.122 \\
MC1 & -0.058 & -0.044 & 0.101 \\
MC3 & -0.089 & -0.067 & 0.157 \\
MC4 & -0.066 & -0.050 & 0.116 \\
MC6 & 0.055 & 0.036 & -0.091 \\
EF1 & 0.125 & 0.124 & -0.249 \\
EF3 & 0.043 & 0.034 & -0.077 \\
FAR & -0.076 & -0.108 & 0.184 \\
APC7 & -0.092 & -0.127 & 0.219 \\
NC & -0.112 & -0.076 & 0.188 \\
\hline Note: ${ }^{a}$ Only for those variables with levels of significance lower
\end{tabular}

get an idea of the effect of any of the dummy variables which are used as independent variables taking on the value 0 to 1 , a calculation was made of the variations in the probabilities of each response in the face of changes in all the variables when the rest of the independent variables adopt their average value in the sample.

Table 10 gives the effect of the most significant variables on the probabilities of each response from the representative firm (with average characteristics), showing that if, for example, the parameter of the variable which is altered is positive, the probabilities of the firm indicating that co-operation without a proyecto concertado was 'improbable' or 'not very probable' are lower, whereas the probability of the response being 'probable' or 'very probable' rises.

\section{Continuation of co-operation}

The estimation of the ordered probit which explains the continuation of co-operation established between firms and PRCs which have participated in proyectos concertados has resulted in a model which correctly predicts $59 \%$ of the responses (Table 11). Firms' intentions with respect to the maintenance of established relationships do not depend in any significant way on their size.

On the other hand, those which had previously carried out proyectos concertados (PCS) show a greater willingness to continue the relationship, as do those which had other types of links (COLNPC). In this second case, the effect is not significant, which may be logical if we take into account the diversity of relationships which could fall into this category (contracted research, joint participation in national or European R\&D programmes, and so on).

It can be seen that the firms which claim that the project would have been viable without the necessity of co-operation (FACA) tend to be less interested in continuing to co-operate with the PRC. Furthermore, the acquisition of experience or knowledge (MC1) or the access to research infrastructures not available
Table 11. Ordered probit model: the continuation of cooperation

\begin{tabular}{|c|c|c|c|}
\hline \multicolumn{4}{|c|}{ Dependent variable: COP } \\
\hline \multicolumn{4}{|c|}{ Maximum of likelihood function: -228.6119} \\
\hline \multicolumn{4}{|c|}{$\begin{array}{l}\text { Restricted (constant only): }-278.19 .{ }^{2}(42)=99.15 \text { Level of } \\
\text { significance: } 0.000\end{array}$} \\
\hline Variable & Coefficient & t-student & Significance \\
\hline Constant & 0.238 & 0.41 & 0.676 \\
\hline $\mathrm{P} 1$ & 0.155 & 0.42 & 0.672 \\
\hline P2 & 0.125 & 0.40 & 0.689 \\
\hline P3 & 0.304 & 0.87 & 0.384 \\
\hline P4 & 0.043 & 0.14 & 0.882 \\
\hline COLNPC & 0.219 & 0.23 & 0.355 \\
\hline PCS & 0.468 & 1.73 & 0.082 \\
\hline FACA & -0.333 & -1.73 & 0.082 \\
\hline MC1 & 0.330 & 1.58 & 0.112 \\
\hline MC2 & -0.334 & -1.49 & 0.133 \\
\hline MC3 & 0.118 & 0.62 & 0.529 \\
\hline MC4 & 0.358 & 1.79 & 0.072 \\
\hline MC5 & 0.257 & 1.26 & 0.206 \\
\hline MC6 & -0.153 & -0.81 & 0.413 \\
\hline EF1 & -0.231 & -1.11 & 0.263 \\
\hline EF2 & -0.011 & -0.06 & 0.948 \\
\hline EF3 & 0.078 & 0.41 & 0.679 \\
\hline AR & 0.170 & 0.41 & 0.676 \\
\hline $\mathrm{BIO}$ & -0.089 & -0.19 & 0.848 \\
\hline ESP & 0.188 & 0.44 & 0.657 \\
\hline FORM & 0.392 & 0.72 & 0.470 \\
\hline ALI & 0.234 & 0.57 & 0.563 \\
\hline MAT & 0.183 & 0.51 & 0.609 \\
\hline FAR & 0.506 & 1.18 & 0.235 \\
\hline APC1 & 0.310 & 1.56 & 0.117 \\
\hline APC2 & -0.006 & -0.03 & 0.974 \\
\hline APC3 & 0.372 & 1.41 & 0.155 \\
\hline APC4 & -0.020 & -0.11 & 0.912 \\
\hline APC5 & -0.037 & -0.12 & 0.898 \\
\hline APC6 & 0.141 & 0.55 & 0.581 \\
\hline APC7 & -0.084 & -0.33 & 0.737 \\
\hline DL3 & -0.536 & -1.57 & 0.114 \\
\hline DC1 & 0.301 & 0.73 & 0.461 \\
\hline DC2 & -0.260 & -0.93 & 0.348 \\
\hline DC3 & -0.570 & -2.12 & 0.034 \\
\hline DC4 & 0.032 & 0.10 & 0.919 \\
\hline DC5 & -0.125 & -0.49 & 0.618 \\
\hline DC6 & -0.564 & -2.17 & 0.029 \\
\hline DC7 & -0.142 & -0.61 & 0.537 \\
\hline DC8 & 0.899 & 1.55 & 0.119 \\
\hline DC9 & -0.008 & -0.01 & 0.986 \\
\hline EXPA & 0.603 & 2.55 & 0.010 \\
\hline NC & 0.166 & 0.80 & 0.422 \\
\hline$\mu(1)$ & 1.534 & 11.00 & 0.000 \\
\hline
\end{tabular}

within the firm (MC4) lead firms to maintain links with the PRC, as does the lower cost for the firms in 
Table 12. Variation in the probability of response in the face of changes in the independent variables ${ }^{\text {a }}$

\begin{tabular}{lccc}
\hline Variable & $\begin{array}{c}\text { Improbable or } \\
\text { not very } \\
\text { probable }\end{array}$ & Probable & Very probable \\
PCS & -0.130 & -0.016 & 0.147 \\
FACA & 0.098 & 0.002 & -0.100 \\
MC1 & -0.098 & 0.000 & 0.098 \\
MC2 & 0.102 & -0.006 & -0.096 \\
MC4 & -0.106 & 0.000 & 0.106 \\
MC5 & -0.074 & -0.005 & 0.079 \\
FAR & -0.125 & -0.047 & 0.172 \\
APC1 & -0.090 & -0.004 & 0.094 \\
APC3 & -0.100 & -0.020 & 0.120 \\
DL3 & 0.182 & -0.049 & -0.132 \\
DC3 & 0.193 & -0.051 & -0.142 \\
DC6 & 0.190 & -0.049 & -0.141 \\
DC8 & -0.184 & -0.142 & 0.326 \\
EXPA & -0.200 & 0.045 & 0.154 \\
\hline
\end{tabular}

Note: ${ }^{a}$ Only for those variables with levels of significance lower than 0.25

carrying out the project (MC5), although this is not as significant. However, the relationship tends not to be sustained when the reason behind co-operation is to be up-to-date on the latest technological or scientific advances in specific areas (MC2). The PRCs' contributions which lead to a continuation of co-operation are 'new methods or techniques' (APC1) and 'designs' (APC3), while the rest are not significant.

With regard to the role played by the proyectos concertados' funding, only those firms which carry out the project thanks to this funding (EF1) show less interest in subsequent co-operation. The most noteworthy is that this effect is not produced if the public aid brought the project forward or enabled it to enjoy more resources (EF2 and EF3), nor when cooperation had been established because it is a requirement for receiving funding (MC6).

The national programme does not influence the firms' responses, although the pharmaceutical $R \& D$ projects (FAR) tend to be associated with greater continuation of co-operation. Also the firms which have answered more than one questionnaire indicate a slightly above-average level of continuation, although the effect is not very significant.

The influence of the proyecto concertado itself upon subsequent co-operation is positive when the firms consider that the results of the project have had a high degree of coincidence with their expectations (224 cases). In contrast, it is negative when coordination problems have appeared which have got in the way of the achievement of the results of the project (DL3) and, also, when a lack of resources on the part of the firm (DC3) or the existence of cultural barriers between the firm and the PRC (DC6) are indicated. What is not explained is that the existence of problems with the confidentiality of results (DC8) has a positive effect on the continuation of co-operation. Perhaps this is because of the limited number of times this is mentioned (18 times).

Finally, the parameter (1), which gives the value of the latent variable from which continuation becomes 'very probable' as opposed to 'probable', is positive and highly significant.

Table 12 shows the variation, in the face of changes in the most significant dummy variables, of the probability of firms' responses to whether they intend to continue co-operating with the $\mathrm{PRC}$ once the proyecto concertado ends. If the parameter of the variable which is altered is positive, the probability that the firm will answer 'improbable' or 'not very probable' has to decrease, while the probability of it answering 'very probable' increases. In the first instance, the effect on the probability of the answer being 'probable' is ambiguous.

In general, in the estimated model, the effect is negative, but when the firm describes the fulfilment of its expectations as being 'very high', the probability of continuation being 'probable' increases. If the reasons for co-operation are access to specialities or acquisition of experience of knowledge (MC1) and the access to infrastructures (MC4) the probability of the answer being 'probable' is unaltered.

\section{Conclusions}

The objective of this paper was to determine whether the proyectos concertados have been a useful instrument in the generation of co-operation between firms and public research centres and whether collaboration with the participant PRC continues after the public financing ends.

Firms' answers indicate that, indeed, the proyectos concertados have often allowed the setting up of contacts between firms and PRCs which would not otherwise have existed. In accordance with the results obtained in the first ordered probit model, where the causes of this co-operation are analysed, it is observed that, in part, collaboration may have been established with firms which are used to carrying out joint $R \& D$ activities with PRCs, but that in the particular project in question they do so only because of the public intervention (variables PCS and COLNPC).

In other cases, firms which would have liked to co-operate, but which found it difficult to gather the necessary resources to embark on the project, have been able to do so thanks to the proyecto concertado (as indicated by the parameters of variables EF1 and EF3). Lastly, firms which did not wish to co-operate have been obliged to do so in order to receive the public funding (MC6).

The existence of these three different attitudes towards relationships with PRCs makes it impossible to carry out just one diagnosis of the usefulness of the public intervention. Thus, the necessity to support the first group of firms does not seem clear, since cooperation may be forced when it is not necessary in a particular project. In addition, even though attitudes 
towards collaboration may gradually improve as relationships become closer, it is not valid to say that all the firms wish to continue to co-operate. At any rate, it seems fitting to point out that, although reiterated support for the same firms may seem appropriate, this situation will eventually become sterile.

The contribution of public funds to projects carried out by the second group of firms seems adequate, not because it promotes co-operation but because it allays the financial problems which firms must face. The third group is the one which most clearly justifies intervention since it draws the firms towards relationships which they do not consider useful, but which can prove to be truly advantageous for them.

The estimation of the equation of co-operation generation also provides evidence about the main reasons considered by firms when it comes to the intervention by PRC researchers. Access to qualifications not otherwise available within the firm and to infrastructures and, less significantly, the acquisition of experience and knowledge are the most important motives. With regard to the specific contributions of PRCs, cooperation only tends to occur in the absence of a proyecto concertado when it consists of prototypes or pilot plants.

In order for the generation of co-operation constituted by the proyectos concertados to have a greater impact, it must tend to be sustained. Firms' responses suggest that the instance of continuation of collaboration between firms and participant PRCs is high. In fact, the significance of the parameters of the ordered probit which explains continuation is relatively low, almost certainly because of the small variability of responses, since the majority are in favour of continuation of co-operation.

However, it is interesting to point out that the coefficients of the variables which indicate financial difficulties are not significant. The same is true of the variable which provides information as to whether the firm collaborated only to fulfil the requirement imposed by the proyectos concertados. This indicates that co-operation continues independently of whether it was first established mainly as a means of receiving public funds. Even so, it can be seen that those firms which did not intend to co-operate are the ones which show less continuity in their links with PRCs.

Finally, it can be deduced from the results of the estimation of the equation that the difficulties which have arisen in co-operation have not had any important effects on its continuity. The subsequent relationship only tends to suffer as a consequence of co-ordination problems or because of the existence of cultural barriers between firms and PRCs.

In synthesis, the proyectos concertados seem to be a useful instrument in the generation of co-operative $\mathrm{R} \& \mathrm{D}$ and, furthermore, they create stable links between firms and PRCs. In this way, the proyectos concertados appear to be contributing to changing firms' minds on co-operation with PRCs.

\section{Notes}

1. The co-operative projects are a recent instrument. The first call for applications was in 1995.

2. Part of the results obtained in this report has been synthesised by Revilla et al (1999).

3. The estimation of this equation using the four answer categories offers very similar results. The problem arises because of the small effect of changes in the dummy variables on the probability of the firm responding that co-operation was very probable without a proyecto concertado

4. The studies by Gibbons and Johnston (1974), Senker and Faulkner (1992) and Faulkner and Senker (1994) have covered the links between firms and PRCs.

5. Among the studies which have analysed the importance of the problems which arose in the relations between firms and PRCs are those of Dean (1981), Azároff (1982), Fowler (1984), Höglund and Persson (1987) and van Dierdonck et al (1990).

6. It is important to point out that the question which was put to firms was whether co-operation took place, not whether they wanted it to. That is why information is available as to whether more effective collaboration was generated. Since, as already mentioned, part of this new co-operation takes place when there are funding problems for the project, it becomes necessary to introduce into the model information about the importance of the public financing in the viability of the project.

7. From 2000 onwards, the prioritisation of the research funded by the National Plan will be based on technological areas and sectors of activity.

8. The information used corresponds to those firms which answered a questionnaire. If the firms which were least satisfied with the proyectos concertados are less prone to answering the questionnaire than the others, the analysis gives a more positive vision than corresponds to reality.

9. Some variables have been maintained which refer to the research project itself since it can affect the subsequent research to be conducted as well as the evaluation the firm makes of future collaboration.

\section{References}

L V Azároff (1982), "Industry-university collaboration: how to make it work", Research Management, 3, pages 31-34.

Comision Interministerial de Ciencia y Tecnologia (1999), "Memoria de actividades del Plan Nacional de I+D en 1997 (CICYT, Madrid).

C W Dean (1981), "A study of university/small business interaction for technology transfer", Technovation, 1, pages 109-123.

W Faulkner and J Senker (1994), "Making sense of diversity: public-private sector research linkage in three technologies", Research Policy, 23(6), pages 673-695.

D R Fowler (1984), "University-industry research relationships", Research Management, 1, pages 35-41.

M Gibbons and R Johnston (1974), "The roles of science in technological innovation", Research Policy, 3, pages 220-242.

W H Greene (1991), Econometric analysis (MacMillan Publishing Company, New York).

L Höglund and O Persson (1987), "Communication within a national R\&D system: a study of iron and steel in Sweden", $R e-$ search Policy, 16(1), pages 29-37.

A Modrego (1995), Evaluación de los Proyectos Concertados del Plan Nacional de $1+D$, informe entregado al Centro para el Desarrollo Tecnológico Industrial.

E Revilla, R Domenech, A Modrego, J Acosta and J Riverola (1999), "R\&D alliances between firms and public research centres to enhance competitiveness. A Spanish empirical evidence", in Technology Strategy and Strategic Alliances. Selected papers from R\&D Management Conference (Fundación COTEC, Madrid).

J Senker and W Faulkner (1992), "Industrial use of public sector research in advanced technologies: a comparison of biotechnology and ceramics", R\&D Management, 22(2), pages 157-175.

R V van Dierdonck, K Debackere and B Engelen (1990), "University-industry relationships: How does the Belgian academic community feel about it?", Research Policy, 19(6), pages 551-566. 